\title{
The Impact on locomotor skills in children. The promotion of significant Knowledge supported by the use of videogames.
}

\author{
Yaneth P. Caviativa ${ }^{1}$ \\ ${ }^{1}$ Universidad Manuela Beltrán. Av. Circunvalar No. 60-00, Bogotá, Colombia
}

\begin{abstract}
Research on attentional processes and their relationship to the maturation of locomotor patterns involved in the use of some types of video games. For this reason, the aim of this study is to identify the influence of the practice of virtual reality games in attentional processes related to the jump motor pattern in children of 5 years. The research was conducted by a quantitative study design using SPSS crosstabulation longitudinal observational period with a pre-test, post-test and a control group. There are few studies on the effect of virtual reality games in the development of locomotor patterns, the study is consistent with research that finds positive effects of this type of games in learning motor activities. In this investigation it was found According to statistical chi-square can conclude that the development of motor skills SI influences meaningful learning of children, Most children engaged in meaningful learning, but they have a necessary guide or a process to follow, according to research must always be supervised by an adult sometimes do not need any supervision, in addition to the significant knowledge not articulated with educational processes guided by the teacher before the motor skills expected
\end{abstract}

\section{Introduction}

Videogames are a worldwide reality, which impact has increased in children and teenagers due to multiple occupations such as academicals and familiar, and so they fill familiar weaknesses like unavailable time to spend with relatives, by using these games in their free time very often, and it becomes much more appealing when the access to internet makes easier this activity.

Communication and Information Technologies (CIT), as well as virtual reality games, have become strategically allies in learning processes, since interaction increases motivation, a process that lies behind learning. In this sense (Gómez, 2013) affirms that:

"The presence and interaction are two fundamental properties of virtual reality systems. It is called presence to the sensation of "being in" the virtual environment. Subjects that go through virtual reality environments do not have the sensation of

Corresponding author: janeth.caviativa@umb.edu.co

\begin{abstract}
observing these from the outside, but being part of them. This feature has made the investigators to think that simulation, for instance, of phobic situations through virtual reality could be used as an intermediate way of exposition between real life and imagination. Likewise, in investigation of cognitive rehabilitation, new options can be offered through games of virtual reality where by using the mouse of computer, the patient can interact with the virtual world." [1]
\end{abstract}

Due these findings, it can be inferred that there is a relation between the use of virtual reality games and maturity of basic locomotor patterns. it allowed to prove significant development of locomotor patterns like running and jumping. In the experience they were stimulated through the video game.

Even though the different uses of virtual reality games, some studies have seen negative effects derived from its practice, especially for visual system [2] and muscleskeletal system [3].

Researches recommend increasing the investigations about attentional processes and their relation with maturity of locomotor patterns involved in the usage of 
these types of videogames. For this reason the objective of the present study is to identify the influence of the practice of virtual reality games on attentional processes related to the jump motor pattern in 5 years old children.

\section{Videogames}

A videogame is an informatic interactive program destined to entertainment that can work in different devices: computers, consoles, cellphones, etc.; it integrates audio and video, and allows enjoying experiences that, in many cases, would be very difficult to live in reality.

Among the features of videogames there can be found: graphics quality (in the beginning in two dimensions, nowadays in three), the control of the game should be easy and intuitive, and sound (from speaker to surroundings) [4]

There are different types of videogames, such as named adventure games (with intelligence tests or puzzles solving to advance), arcade (skill activities), sports, strategy (coordinate actions), role (where the player moves a character and evolves throughout the game according to his decisions), and simulation (some kind of action is simulated, for example, flying a plane) [4]

Virtual reality games are classified in an exclusive range of tools, in which the user can venture creatively, until the limit of their imagination allows it. There lays, possibly, the mayor attraction, since imagination and creativity have the opportunity of happening in an artificial and unlimited "world". The origin of these games is the defense department of the United States of America, where they were created as material for an aviation class in the 70's to complete flying simulations by practicing and not risking lives [5]

\section{Learning and psychomotor development}

Da Fonseca, (2010), affirms that:

\begin{abstract}
"Maturity without the opportunity of "motor experiences" leaves to half way the development and the capacity of learning in children. We are born with an inconclusive relation between body and brain that has no ways of communication or interaction. It is the development of motor skills what will proportionate that narrow communication between the center and the periphery of the body. The motor skills are related and develop simultaneously with emotional functioning. Which is, body and its manifestation, in whichever of its ambits, contain in their basis, an emotional component. [6]
\end{abstract}

Thus, the function of motor skills in the capacity of learning is very important when the child has initiated his preschool level and the teachers expect that the students are ready in their physic and mental functions so they continue to receive knowledge.

\begin{abstract}
"There is a reciprocal action between mental functions motor functions, psychological development and neurological development. The experiences that each child has with his body and his motor system will be a very important factor to fortify the development of their neural network system, and at the same time, the development of the neural system eases on the children the exploration and discovering of their capacities to practice different types of movements, promoting so, their autonomy, development of their identity and the organization of their thoughts." [7]
\end{abstract}

In children, the ideal is that the motor skills of their movement have progression throughout years, which is why:

\begin{abstract}
Psychomotor skill is an activity that gives a psychological significance to movement, in which each new ability develops from other less organized that allows to integrate and coordinate functions of psychic life with the movement, becoming a basic element in learning, since promotes the efficient cognitive process. Psychomotor skill is an activity that eases the integral development of the child. [8]
\end{abstract}

This association is shown in the early stages of the child when their cognitive process are produced by their motor activity, by manipulating and moving objects in their environment, to create significance as a result of the construction of learning by their context, generating that the child stimulates his/her own motor processes and motor abilities. This interrelation should be reinforced by the combination of teaching (mental learning) with motor activities such as using virtual reality games (motor learning).

Motor learning, and so significant learning, can be influenced by virtual reality games through the influence in premotor cortex. This cortex has direct connections with the primary motor area and contributes with the $30 \%$ of axons that conform corticospinal and corticobulbar tract. The premotor cortex is constituted by two components: lateral and medial.

The lateral component facilitates the development of conditional tasks with visual hints, while the medial component participates in the selection and beginning of movements through internal signs more than external motivations [9], virtual reality games can influence directly in processes of motor learning proportionating visual hints and having an impact directly on motivation.

\section{Significant learning}

As López (2015) affirms:

Significant learning is an active restructuration of perceptions, ideas, concepts and schemes that the apprentice possesses in their cognitive structure. We could characterize their posture as constructivist; learning is not a simple passive assimilation of literal information, since subject transforms and structures it. Study materials and external information interact and interrelate with the previous schemes of knowledge and personal characteristics of the apprentice [10]. 
We could say that the significant learning constructs with the experience of each perception and so acquiring knowledge, experiences and generating new concepts.

Children can be considered as an active processor of information, and it is said that learning is systematic and organized, since in its more elaborated stage, consists in something very complex which cannot be reduced to simple memory tasks. Also it is worth pointing out the importance of learning by discovery according to the new facts that the subject perceives, infers, relates and generates ideas. With this one can say that it is not necessary that any significant learning in classroom should happen by discovery.

The previous knowledge of the student is considered in terms of knowledge schemes, which consist in representation that a person possesses in a specifically moment of their history about a piece of reality. These schemes include different types of knowledge about reality, such as: facts, experiences, personal anecdotes, attitudes, rules, etc. There are different types of significant learning since each one of them is related to requirements of human being to acquire beneficial knowledge for their own usage.

\section{Motor patterns}

Children develop skills in movement in a progressive way, from first involuntary moves to highly complex skills. Early childhood period ( 2 to 7 years) is critic for the development of elemental motor patterns. Children that do not develop mature motor patterns during this period, frequently present difficulties in carrying out complex motor abilities such as sport gestures.

Locomotor patterns are those movements that allow children the exploration of space. Like walking, running, high and extension jumping, leap, gallop and climb. [11]:

\section{Methodology}

This investigation work was developed through a quantitative study with a observational period of experimental and longitudinal type, with pre and post measures in a control and experimental group during six months. It was developed with the interaction of a videogame towards significant learning for locomotor development in these children.

The population of the study fulfilled the following inclusion criteria: children of preschool who belong to Manuela Beltrán school in Bogotá, who have not practiced real sport games, and the sign of informed assent and consent.

Later, the size and weight of children were compared obtaining their body mass index (BMI) with the help of the statistic program used in educative levels SPSS indicating chi-square, and with the help of contingency chart lower than 0,05 , it could be identified if there is an influence of videogames over locomotor patterns of jumping in preschool children.

\section{Results}

The total population of the study was 30 children; from which 15 belong to control group and 15 to intervention group. The characteristics of size and weight of both populations are presented in chart 1. From this data (weight and size) the BMI was obtained.

\section{Chart 1.}

\begin{tabular}{|c|c|c|c|c|}
\hline & \multirow{2}{*}{$\begin{array}{c}\text { BMI }<16 \\
\text { Selected }\end{array}$} & \multirow[b]{2}{*}{ Total } \\
\hline & & & & \\
\hline \multirow[t]{8}{*}{\begin{tabular}{|l|} 
Control \\
\end{tabular}} & No & Recount & 6 & 6 \\
\hline & & $\%$ within control & $100.0 \%$ & $100.0 \%$ \\
\hline & & $\%$ within $\mathrm{BMI}<16$ & $37.5 \%$ & $37.5 \%$ \\
\hline & & $\%$ of total & $37.5 \%$ & $37.5 \%$ \\
\hline & $\overline{\text { Yes }}$ & Recount & 10 & 10 \\
\hline & & $\%$ within control & $100.0 \%$ & $100.0 \%$ \\
\hline & & $\%$ within $\mathrm{BMI}<16$ & $62.5 \%$ & $62.5 \%$ \\
\hline & & $\%$ of total & $62.5 \%$ & $62.5 \%$ \\
\hline \multirow[t]{4}{*}{ Total } & & Recount & 16 & 16 \\
\hline & & $\%$ within control & $100.0 \%$ & $100.0 \%$ \\
\hline & & $\%$ within $\mathrm{BMI}<16$ & $100.0 \%$ & $100.0 \%$ \\
\hline & & $\%$ of total & $100.0 \%$ & $100.0 \%$ \\
\hline
\end{tabular}

Chi-square tests

a. It will not be calculated any statistic because

\begin{tabular}{|l|r|}
\hline & \multicolumn{1}{|l|}{ Value } \\
\hline Chi-square of Pearson & $\dot{\mathrm{a}}$ \\
Number of valid cases & 16 \\
\hline
\end{tabular}

$\mathrm{BMI}<16$ is a constant.

\section{Chart 2.}

Summary of cases processing

\begin{tabular}{|l|r|r|r|r|r|r|}
\hline \multirow{2}{*}{} & \multicolumn{6}{|c|}{ Cases } \\
\cline { 2 - 7 } & \multicolumn{2}{|c|}{ Valid } & \multicolumn{2}{c|}{ Lost } & \multicolumn{2}{|c|}{ Total } \\
\cline { 2 - 8 } & $\mathrm{N}$ & Percentage & $\mathrm{N}$ & Percentage & $\mathrm{N}$ & Percentage \\
\hline Control * BMI $<16$ & 16 & $100.0 \%$ & & $0.0 \%$ & 16 & $100.0 \%$ \\
\hline
\end{tabular}

There is influence of videogames over locomotor pattern in preschool children since they learn by discovery generating a significant learning.

Besides we can conclude that significance in significant learning of videogames in preschool children helps in abilities like jumping helping therefore their motor skills. 
Virtual reality games give a motor learning. Through the participation that children have in motor exercises in the scholar age, maturity in brain starts to increase in the experience of learning, at the same time with the perception and interaction with their scholar, family and social environment, which favors that the knowledge is received with pleasure and displayed for children as easy and fun.

\section{Conclusion}

In this investigation, it was found that according to chisquare statistic, it can be concluded that development in motor skills DOES influence in significant learning of boys and girls. Most of them do activities of significant learning, but do not have a necessary guidance or a procedure to follow. According to investigation they have to be always supervised by an adult but sometimes they do not need to have any kind of supervision, besides that significant knowledge does not articulate with didactic processes orientated by the teacher in the face of the expected motor skill.

In the beginning, they were only a group of exercises that were used to fix some weakness, disability or difficulty. But with the pass of the years, now is very important in childhood education, and even more so in early years of childhood due to the existence of interdependence between motor, affective and intellectual development.

\begin{abstract}
"The strategy itself can be determined being also a group of actions directed to the consecution of a goal, implying steps to be taken to obtain significant learning, and so securing the consecution of an objective: taking into account the capacity of thoughts which allows advancement in function of effectiveness criteria" [12]
\end{abstract}

Its final purpose is to regulate activity in people, its application allows to select, evaluate, persist or abandon different actions to achieve goals that we will propound, they are independent; imply auto direction; the existence of an objective and the conscious of that objective exists and auto control; the supervision and evaluation of the own behavior in function of objectives that guide them and the possibility of printing modifications on it whenever its necessary and according to the necessities and contexts where these didactic strategies are going to be applied.

Virtual reality videogames help as strategies in significant learning since they focus the attention and stimulate activity, jumping and motor skills in children of preschool age.

\section{Acknowledgment}

The author would like to thank Richard Jose De Sousa Da Silva for his translating collaboration and adjustment of the text to the corresponding and required format.

\section{References}

[1] GÓMEZ MORA, M. Aplicación de realidad virtual en la rehabilitación cognitiva. En: Revista Vínculos.

Ciencia, Tecnología y Sociedad. Enero-junio, 2013. Vol 10 , no $1.130-135$.

[2] MURCIA P. L., Incidencia del uso de los videojuegos en alteraciones visuales, ergonómicas en niños de 9 a 14 años [en línea]. En: Ciencia y Tecnología para la salud visual y ocular. 2004. Disponible en internet [citado en 18 Noviembre de 2013].

[3] BELTRÁN V. J., VAlenCiA A., MOLinA J. P., Los videojuegos activos y la salud de los jóvenes: revisión de la investigación. En: Revista internacional de medicina y ciencias de la actividad física y el deporte, Marzo, 2011, Vol. 11, no 41, p. 203-219.

[4] GALEÓN. Historia de los Video juegos, [en línea] 2012. Disponible en internet: www.historiavideojuegos.galeon.com [citado en 25 Junio de 2012].

[5] PÁEZ A., Realidad Virtual, [en línea] Monografias.com, 2007. Disponible en internet: http://www.monografias.com/trabajos53/realidadvirtual/realidad-virtual.shtml [citado en 25 Junio de 2012].

[6] Da Fonseca, V. (2010, p. 304). Manual de observación Psicomotríz. Obtenido de https://books.google.com.ec/books?id=kNrRlgjAoY $\mathrm{EC} \&$ printsec $=$ frontco ver $\# \mathrm{v}=$ onepage $\& \mathrm{q} \& \mathrm{f}=$ false

[7] Vásquez, M. (14 de Julio de 2014, p. 12). Experiencias de aprendizaje sobre corporalidad y movimiento. Obtenido de http://es.slideshare.net/miriamcita/20130726181559 0libro2corporalidad

[8] Ortega, X. (5 de Febrero de 2013). Trabajos del libro e Psicomotricidad. Obtenido de http://xjog60.blogspot.com/2013/02/6-mepp.html

[9] PURVES, D. Neurociencia. Editorial Médica Panamericana. 2007.

[10] López, W. (2015, p. 26). La percepción visual y su incidencia en el desarrollo del aprendizaje significativo. Obtenido de http://repo.uta.edu.ec/bitstream/123456789/18605/1/ TESIS $\% 20$ con $\% 20$ fir mas.pdf

[11] Mc CLENAGHAN Y GALLAHUE. Movimientos fundamentales su desarrollo y su rehabilitación. Editorial Panamericana. 1985. 
[12] Sarmiento, A. (2012). Definicion de estrategia didactica. Obtenido de https://antonio6519.wordpress.com/2009/10/05/defi nicion-de-estrategiadidactica/ 